\title{
Police Strategy in Social Control during Large-Scale Social Restriction (PSBB)
}

\author{
Amir Hamzah ${ }^{1}$, Megawati Barthos ${ }^{2}$ \\ \{Amirhamzahh4848@gmail.com ${ }^{1}$, megawati_barthos@borobudur.ac.id ${ }^{2}$ \} \\ Universitas Borobudur, Jakarta, Indonesia ${ }^{1,2}$
}

\begin{abstract}
This paper analyzes the police strategy in the context of social control to the community during the Large-Scale Social Restrictions (PSBB). Through a normative juridical approach with a literature study, it was found that the implementation of the PSBB requires special handling from the Police so that security stability is maintained. The Police took strategic steps by forming a task force and activating the role of the cyber-police to be able to ward off hoaxes, including proper and measurable implementation based on the information from the Chief of Police.
\end{abstract}

Keywords: Security; Police; Social Control; Large-scale Social Restriction (PSBB)

\section{Introduction}

The Large-Scale Social Restriction Policy (PSBB) is one of the efforts taken by the government and aims to reduce the spike in the number of Covid-19 spreads. The government seeks to protect the community by providing recommendations regarding actions that must be taken and need to be adhered to by society to reduce its spread. The Covid-19 incident is one of the social problems that is being faced by the Indonesian people, even throughout the world. Based on these events, many cases occur in the community, such as incompatibility between social values and social actions, social organizations that cannot organize community members to be harmonious.[1]

One of the important issues in society is the stability of national security. It is because the government had implemented a lockdown policy, so this triggered the economy to plummet. People are doing ways that violate the law and cause the crime rate to be high.[2] There is a growing perception that people feel they have not received maximum legal protection during the pandemic. It has resulted in tremendous pressure for the Government of Indonesia to deal with or fight the Covid-19 pandemic.

The security and stability of a country must be guaranteed by the government, so that the people, whether individually, in groups, or as a whole, get peace and comfort in carrying out their daily activities. Security and stability assurance should be based on law, knowledge, and technology. Legal-based security and stability assurance is formulated in the legal system applicable in the country or internationally, as abbreviated in laws, government regulations, and other legal methods. Knowledge-based security and stability assurance means that dynamic efforts to develop stability and security are based on scientific principles. Assurance 
of technology-based security and stability means a forceful attempt to improve solidity and protection by utilizing technology and all its advances.[3]

The increased unemployment accompanied by the release of prisoners as a result of the handling of the Covid-19 pandemic requires the government to involve the security forces in handling it. One of the things involved in maintaining security stability is the police report. In their duties, National Police issues strategies that should be complied by the local area and will always be supervised by the POLRI to implement the policies that have been set. Itis is in the context of protecting and guaranteeing security for the community. The Covid-19 pandemic also requires the Indonesian National Police to play a role in disease control efforts, educates the public, and takes action against crimes that see the outbreak as an opportunity to commit various crimes.[4]

Pros and cons have emerged regarding the involvement of the police in participating in securing large-scale social restrictions (PSBB) policies in Indonesia. Based on this description, some problems arise, including what is the urgency and to what extent is the police strategy in maintaining national security stability during the implementation of large-scale social restrictions (PSBB) during the Covid-19 pandemic?

\section{Method}

This research uses a non-doctrinal method with a normative juridical approach, using a conceptual approach,[5] namely an analysis based on concepts or theories relevant to the research problem, in this case, the research problem is a crime during the COVID-19 Pandemic. The lawful information utilized is optional information acquired through writing study and broke down expressively systematically.[6]

\section{Discussion}

In the spread of the Covid-19 virus, many countries have issued policies to protect their citizens from the deadly threat of the virus. Indonesia became a country that released a policy of establishing large-scale social restrictions (PSBB).[7] In implementing this policy, the government also issued several regulations regarding PSBB. The goal is that the community can carry out policies from the government, and can be socialization for the community as well as guidelines for the community in implementing the PSBB.

There are a few guidelines identified with the execution of the PSBB, including Government Regulation Number 21 of 2020 concerning Large-Scale Social Restrictions in the Context of Accelerating the Handling of Corona Virus Disease 2019 (Covid-19), Regulation of the Minister of Health (Permenkes) Number 9 of 2020 concerning Rules Enormous Scope Social Limitations With regards to Speeding up the Treatment of Covid Illness 2019 (Coronavirus), just as Unofficial law instead of Law (Perpu) Number 1 of 2020 concerning State Monetary Approach and Monetary Framework Soundness for Taking care of the 2019 Covid Infection Pandemic as well as With regards to Confronting Dangers That Imperil the Public Economy and additionally Monetary Framework Dependability. [7]

PSBB status can be applied to an area or province or district or city if it meets criteria such as including the number of positive confirmed cases and deaths that have increased significantly and spread rapidly in several areas. Then it relates to epidemiology with similar events in other regions or countries. If a zone has shown these criteria, the next step is the 
regional head, namely the Governor or Regent or Mayor, must be submitted it. Submissions are followed by data on the increment in the quantity of spreads over the long haul, just as the event of neighborhood transmission occasions. The data is also equipped with a curve about the epidemiology that has occurred in the area. The regional head must also provide information concerning the region's ability in terms of basic living needs that will be provided to the people, health infrastructure facilities, and the operation of social security nets, as well as security aspects.[8]

The implementation of PSBB has a very influential impact on all Indonesian people, including the security sector. Empirical facts show that the determination of the pandemic and the execution of the PSBB make it difficult for the community to meet all their needs. It is constrained due to restrictions in all respects. This factor triggers changes in people's behavior because income is decreasing, they tend to do something against the law to meet their needs. The Frustration Aggression Theory states that: "some people commit specific instrumental crimes, property crimes, to satisfy their needs." Thus, it makes sense that the public will be wary of the potential for criminal acts amid the Covid-19 pandemic.

All forms of violations that occur will certainly disrupt social, economic, political, cultural, and national security stability. In the security sector, what is worried is that if any time the threat of crime arises, both on a small and large scale.[8] Many crimes that occurred during the Covid-19 pandemic are varied from street crime, cybercrime, kidnapping, and theft. The majority of the perpetrators admitted that their actions were due to the economic squeeze as a result of the PSBB policy setting during the Covid-19 pandemic.

The occurrence of layoffs due to this pandemic causes people who are victims of work termination to have difficulty meeting their daily needs. The economic crash sometimes makes people desperate to commit crimes, such as stealing, cheating, robbing, etc. Economic factors are the vehement driving factor for someone to commit a crime in some criminal acts, enhance what he calls "subjective Nahrungschwerung" (unemployment) is additionally something that empowers wrongdoing during a pandemic. Similarly as there was a huge scope action limitation to forestall the spread of the Covid, it impacted people's livelihoods.[9]

The potential for increased criminal acts requires efforts to be overcome by the existing apparatus. Wrongdoing anticipation is basically an indispensable piece of social guard endeavors and endeavors to accomplish social government assistance, along these lines, a definitive objective or essential objective of wrongdoing avoidance is the assurance of the local area to accomplish public thriving. Concerning securing people in general identified with the wrongdoing during the COVID19 pandemic, one of which is through the obligations and elements of the Indonesian Police.

Based on Article 13 of Law Number 2 of 2002 concerning the Indonesian Public (Police Act), the primary undertakings of the Indonesian Public Police are: (1) keeping public security and control; (2) uphold the law; and (3) give assurance, insurance, and administrations to the local area.

The leftover obligations are directed in Article 14 of the Police Law. Concerning the precautionary undertakings and elements of the National Police, as indicated by Awaloeddin Jamin, practically speaking in the field, the Police allude to this preplanned term as "local area improvement" or "circuitous preventive," to be specific training pointed toward causing the local area to become well behaved residents. Preventive tasks or functions are divided into two major groups: (a) Physical prevention by carrying out four main activities, including regulating, guarding, guarding, and patrolling; (b) Prevention is coaching in nature by carrying out counseling activities, guidance, direction, continuation, and forums to create a society that is aware and obedient to the law and has the power to prevent crime. In this second point, 
what is called preemptive or indirect preventive action. Efforts to tackle the crime of robbery are quite comprehensive that have been carried out by the Indonesian National Police (police of the Republic of Indonesia) as law enforcers, which consist of pre-emptive, preventive, and repressive efforts. [10]

The strategy of law enforcement officers (APH) in this case, the police has its way of dealing with crime during the COVID-19 pandemic in the form of:[11] One of them, the police are entrusted with planning regions inclined to the spread of the Covid as a preventive measure. As a preventive measure, the police direct watches in regions inclined to the spread of the infection, do observation like estimating internal heat level and splashing public spots with sanitizer fluid, keeping the separation, and practice clean living. The Police are on the job with making a move against culprits of violations, for instance, accumulating of essential products. Police positions are likewise accountable for getting ready confinement spaces for patients contaminated with the Covid, planning offices and wellbeing laborers, just as giving help to the groups of suspected Covid patients. At the point when a wrongdoing happens, the Police don't spare a moment to make a decisive move against the culprits of the wrongdoing.

It is done to give assurances to general society and diminish the space for hoodlums to move. The lawbreakers exploited the circumstance when all centered around taking care of and defeating the spread of COVID-19. The National Police is putting forth attempts to address the elements that reason and urge individuals to carry out violations by giving direction and guiding to exploit the time at home (telecommute). Preventive exercises are likewise completed after their examination and assessment (anev) shows that the increment in the quantity of wrongdoings by effectively watching and protecting spots inclined to wickedness.

The National Police has additionally given a Telegram Letter Number ST/1238/IV/OPS.2/2020. The substance are planned for Kasatgaspus, Kasubsatgaspus, Kaopsda, Kasatgasda, Kaopsres, and Kasatgasres to focus on precautionary and preventive endeavors to lessen crime percentages. The police won't spare a moment to make a firm and estimated move against any culprits of wrongdoings like burglary, robbery, theft, thuggery, to fights. The police have delineated gatherings of lawbreakers including, expanding provincial watch exercises to make security and public request.

Article 93 of the Health Quarantine Law regulates sanctions for PSBB violators. The article explains that people who violate the PSBB regulations will be threatened with criminal sanctions of 1 (one) year and/or a maximum fine of Rp. 100,000,000.00 (one hundred million rupiahs). Synchronous with Article 218 of the Criminal Code also states that maximum imprisonment of four months and two weeks or a maximum fine of Rp. 9,000.00 (nine thousand rupiahs), for anybody, when individuals meet up purposely don't leave following being requested multiple times by or for the skilled position. PP Number 21 of 2020 is also the basis for the authority of the police to act decisively to take action in the context of law enforcement for violators so that criminal sanctions must be applied to people who violate the applicable government regulations.

Related to Article 13 of the POLRI Law during the Covid-19 pandemic, the main tasks of the POLRI were emphasized and detailed again by the issuance of several telegrams from the National Police Chief with regards to getting the circumstance and conditions during the Coronavirus pandemic, including:

1. Telegram Letter Number ST/1098/IV/HUK.7.1/2020 Regarding Handling Potential Crimes During Large-Scale Social Restrictions (PSBB); which regulates the guidelines for police personnel in taking legal action. 
2. Telegram Letter Number ST/1099/IV/HUK.7.1/2020 Regarding Crime Handling in the Task of Availability of Basic Materials and Distribution.

3. Telegram Letter Number ST/1100/IV/HUK.7.1/2020 regulates the handling of crimes in cyberspace.

4. Telegram Letter Number ST/1101/IV/HUK.7.1/2020 regulates the handling of potential crimes during the PSBB implementation period.

5. Telegram Letter Number ST/1102/IV/HUK.7.1/2020 regulates the handling of Indonesian Migrant Workers (TKI) who have just arrived from countries affected by Covid-19.

During the Covid-19 pandemic, the National Police institution also emphasized the function of law enforcement which was confirmed by the issuance of the Chief of Police Decree Number MAK/2/III/2020 on March 19, 2020, concerning Consistence with Government Strategies in Taking care of the Spread of Coronavirus.[12] The announcement was issued taking into account the national situation related to the rapid spread of Covid-19, where the government has issued policies in the context of handling it properly, quickly, and appropriately so that its spread does not spread and develop into a disturbance to the public security and order. Furthermore, it was also emphasized that the Decree of the Chief of Police was set to protect the public. Based on this, the Indonesian National Police always refers to the principle that people's safety is the highest law (Salus Populi Suprema Lex Esto), the Chief of the Indonesian National Police issues a decree so that the public does not hold social activities that cause large numbers of people to gather, either in public places or in public places.

POLRI has a crucial role in preventing and following up on specific crimes that arose during the Covid-19 pandemic.[4] In carrying out its duties to meet the new normal era, the Indonesian National Police has three challenges, namely:

1. Social Communication Strategy During the implementation of PSBB. The level of community discipline is still considered low. In practice, people are still huddled together, do not wear masks, and do not keep their distance.

2. The readiness of POLRI personnel resources. The Covid-19 pandemic has made many individuals experience mass layoffs from their work environment. This condition triggers an increase in crime, such as theft, murder, kidnapping, looting, and other crimes that are motivated by economic factors. Here the POLRI is required to continue to work hard in enforcing the law with the aim of providing community protection during the Covid-19 Pandemic. Indonesia is considered not yet ideal so that the necessary support capacity of POLRI personnel needs to be considered.

3. POLRI is expected to play an immense role in the new normal order. The POLRI has moved quickly by forming the Nusa II Safe Task Force which consists of the Pidum Subsatgas, the Economy Subsatgas, and the Cyber Subsatgas. Each Task Force has its duties. First, the Pidum (General Crime) Subsatgas, is tasked with cracking down on conventional crimes such as theft, looting, robbery, and other general crimes. The second sub-task for the economy is on duty with cracking down on hoarding of food and medical equipment. The three Cyber Subsattas are on duty with taking action against the perpetrators of the Covid-19 hoax through online media.

During the Coronavirus Pandemic crisis, the need of law implementation actions taken by the Indonesian National Police during the Covid-19 pandemic are: (1) Enforcing strict quarantine implementation; (2) Protecting medical personnel; (3) Take action against hoarding of medical equipment and sale of counterfeit drugs; (4) Supervise potential hoaxes that can trigger social conflict; 5) Arrest criminals who commit street crimes. 


\section{Conclusion}

The treatment of wrongdoing during the Coronavirus pandemic that has been done at the POLRI is very extensive, in particular precautionary, preventive, and repressive prevention. However, it is still ineffective where there are several obstacles in its implementation, including large areas, cross-regional perpetrators, victims who do not report or are not quick to report, the community is less responsive and cooperative in providing information, or they do not provide complete information and is afraid to be a witness, IT facilities, less personnel; other agencies are less cooperative. This empirical condition becomes the sociological basis for the Indonesian National Police to participate in supervising the implementation of the PSBB in the community. The National Police Chief issued various regulations to secure the implementation of the PSBB Policy. In addition, the Indonesian National Police also formed a Task Force tasked with cracking down on divers wrongdoings, both regular violations, financial violations, and digital wrongdoings during the Coronavirus pandemic.

\section{References}

[1] R. Ega, " COVID-19 in the Perspective of One Health Approach and Law Enforcement," COVID-19 dalam Perspektif One Health Approach dan Law Enforcement. 2020.

[2] W. Hadiwardoyo, " National Economic Losses Due to the Covid-19 Pandemic," Baskara J. Bus. Enterpreneursh., vol. 2, no. 2, pp. 83-92, 2020, doi: https://doi.org/10.24853/baskara.2.2.83-92.

[3] B. Ambarita, " The Urgency of the National Security Law in National Stability and Synergy," Gener. Kampus, vol. 8, no. 1, 2015.

[4] J. K. Hukum and I. A. Millah, "Crime Prevention During the Covid-19 Pandemic Period (In Perspective of Criminology and Victimology).," J. Komun. Huk. ( JKH), vol. 6, no. 3, pp. 2356-4164., 2020.

[5] J. Ibrahim, "Normative Legal Research Theories and Methods," Bayu Media, Malang, 2006.

[6] I. M. P. Diantha, “ Normative Legal Research Methodology,” Teor. Metodol. Penelit. a., 2017.

[7] F. P. Disantara, “ State Responsibilities During the Covid-19 Pandemic," JCH (Jurnal Cendekia Hukum), vol. 6, no. 1, p. 48, 2020, doi: 10.33760/jch.v6i1.262.

[8] P. S. Saraswati, "Kebijakan Hukum Terhadap Penanganan Pandemi Covid-19 di Indonesia," KERTHA WICAKSANA, vol. 14, no. 2, pp. 147-152, Jul. 2020, doi: 10.22225/kw.14.2.1923.147-152.

[9] A. K. Dewanti, "Layoff Emergency in the Middle of Corona," Arsip Publ. Ilm. Biro Adm. Akad., 2020.

[10] State Secretariat, "Law no. 2 of 2002 concerning the Police.” 2002.

[11] B. T. Rafie, " The National Police Chief releases a telegram for violators of the Covid19 protocol, here's the contents," News Setup Kontan, 2020. https://newssetup.kontan.co.id/news/kapolri-rilis-surat-telegram-untuk-pelanggarprotokol-covid-19-ini-isinya?page=all (accessed Aug. 20, 2021).

[12] " Telegram Letter Number ST/1101/IV/HUK.7.1/2020 regarding the handling of potential crimes during the PSBB implementation period.” 2020. 